\title{
Elimination of Wastes In Die Casting Industry By Lean Manufacturing: A Case Study
}

\author{
Sumit Kumar Singh, Deepak Kumar, Tarun Gupta \\ Assistant Professor Department of Mechanical Engineering NGF College of Engineering and Technology \\ Assistant Professor Department of Mechanical Engineering NGF College of Engineering and Technology \\ Associate Professor Department of Mechanical Engineering NGF College of Engineering and Technology
}

\begin{abstract}
As the competition in market is growing at a very fast pace, one can survive in today's industrial world by adopting the philosophy of Lean Manufacturing. In order to stay competitive, producing cheaper products at a faster rate Lean Manufacturing would help the industry. This paper represents a case study of Die casting industry. This case study is used to illustrate the steps in implementation of lean manufacturing providing actual and very positive results. The implementation plan is based on five major areas of wastes including Defects, Inventory, Excessive material movement, Delay due to waiting and Inappropriate processing in a die casting industry. The suggested implementation plan is being sub divided into three phases.
\end{abstract}

Keywords: - Lean Manufacturing, Die casting, Wastes.

\section{INTRODUCTION}

What if your company could dramatically reduce its production lead time and product costs while increasing its capacity? Most companies make 35 to $75 \%$ improvements on production lead time, reduce production costs by $10 \%$ to $25 \%$, and increase capacity by $20 \%$ to $50 \%$.

What if your company completed customer orders on time? On time deliveries rates increase from $50 \%$ to $90 \%$ with lead times that are less time than your competitors.

Manufacturing operations are continually striving to increase productivity and output of their operations. Their goal is to satisfy the customer with the exact product, quality, quantity, and price in the shortest amount of time. Lean manufacturing is more than a cost reduction program or a problem solving approach (Tapping, 2002). The main idea is that an efficient production can be achieved by a comprehensive approach to minimize wastes. This means eliminating excess production and inventory, redundant movement of material, waiting and delays, over processing, excess worker motion, and the need for rework and corrections.

\section{LEAN MANUFACTURING DEFINITION}

Lean manufacturing is defined as "A philosophy, based on the Toyota Production System, and other Japanese management practices that strives to shorten the time line between the customer order and the shipment of the final product, by consistent elimination of waste". All types of companies, manufacturing, process, distribution, software development or financial services can benefit from adopting lean philosophy. As long as a company can identify a value stream, from when the customer orders product to when they receive it, lean principles can be applied and waste removed.(Singh, 1999).

Also, lean manufacturing is: "Adding value by eliminating waste, being responsive to change, focusing on quality, and enhancing the effectiveness of work force". (Liker, 2004).

Another definition for lean manufacturing: "it is a systematic approach to identify and eliminate waste (nonvalue added activities) through continuous improvement by following the product at the pull of the customer in pursuit of perfection". (Czarnecki and Loyd, 1998).

Also, lean manufacturing is: "A manufacturing philosophy that shortens the time between customer order and the product build/shipment by eliminating sources of waste". (liker and Lamb, 2000).

\section{PROCESS OVERVIEW}

The die casting process is a high production rate casting method that can produce cost effective, primarily nonferrous, products of complex shapes with excellent surface finish, good dimensional tolerances and high material yields. In this method molten alloy is forced into a metal die and allowed to solidify under pressure to take the shape of the die cavity. The basic cold chamber die casting process consists of the following stages:

1). Die closer, where the die halves are brought together and locked with the required clamping force,

2). Landing, where the predetermined volume of melt is ladled into the shot sleeve from the holding or melt furnace,

3). Cavity filling, where the superheated molten metal or alloy is injected at high velocities and under high 
pressure into the die cavity to ensure rapid and complete filling,

4). Melt solidification, where the injected melt is solidified under pressure and under predetermined thermal conditions,

5). Die opening, where the die halves are separated and the solidified casting is ejected by pneumatic or mechanical force, and

6). Die lubrication, where the open die halves are sprayed with lubricants and anti solder compounds.

This process cycle is repeated continuously over long periods for cost effective production of complex, primarily thin walled parts. It is a near net shape manufacturing process in which the cast components can be used in the as-cast condition with little or no machining.

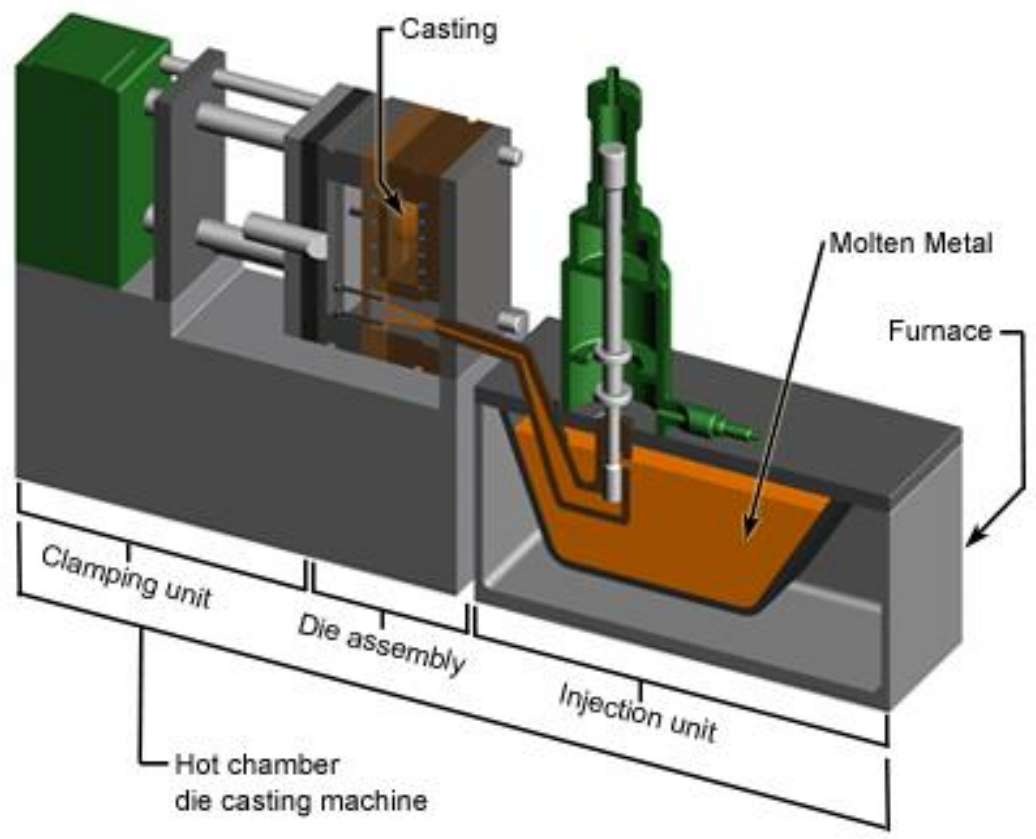

Fig.1.Die casting hot chamber machine

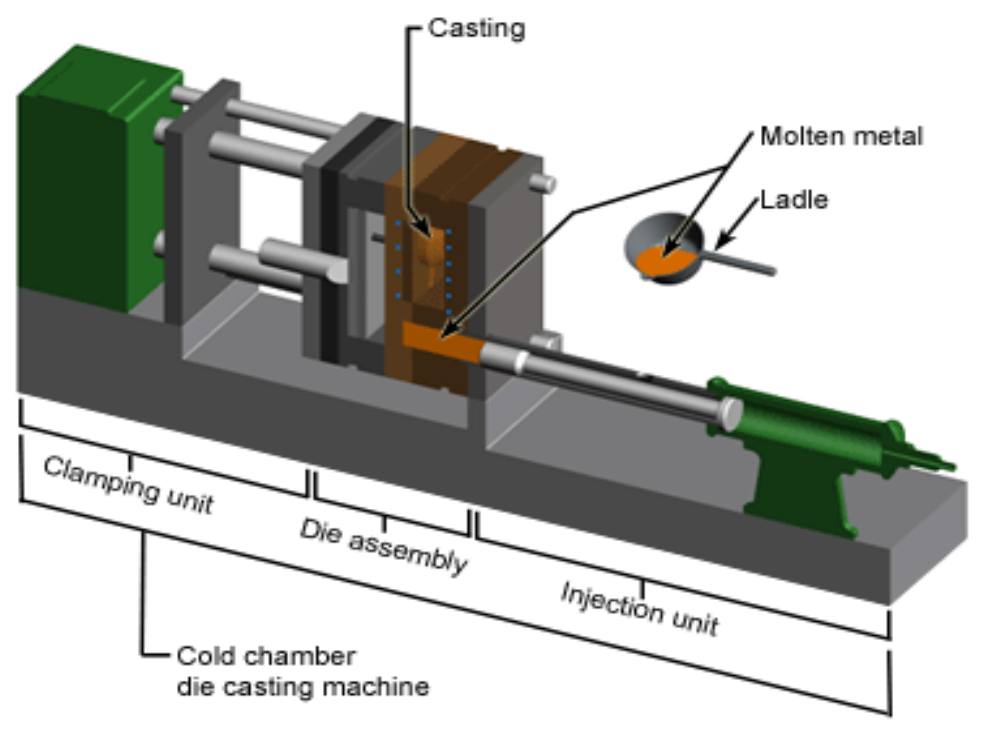

Fig.2.Die casting cold chamber machine

There are two basic die casting processes; hot chamber and cold chamber. The main difference between the two processes is that in the hot chamber process the melt or holding furnace is an integral part of the metal injection system while in the cold chamber process the melt or the holding furnace is a separate unit with a ladling unit as a means of transportation of the molten metal to the injection unit. 


\section{CASE STUDY}

\section{Problem Statement:}

The Company $\mathrm{X}$ is in the field of high pressure die casting of aluminium based alloys. The company is facing a major problem because of high rejection rate of some of its components due to various casting defects. A defect may arise from a single clearly defined cause or result from combination of factors, making it difficult to clarify its original cause. Recent practices are to correct the errors through modifications to the process or the environment, to diagnose the exact cause of the defects.

The purpose of this paper is to identify the causes of various casting defects which arise during the die casting process and eliminate the same.

\section{Suggested Solution:}

\section{GAP ANALYSIS}

Following work has been carried out to identify gaps:

a) Comparison of existing status in the shop with the requirement of lean manufacturing.

b) Using expert opinion and clarify the gap as` $\mathrm{HIGH}$ ',MEDIUM` or 'LOW'

Where

HIGH - Very large gap, need immediate action.

MEDIUM -Large gaps, urgent action required.

LOW -Insufficient gap does not require immediate action.

Table 1 shows the gap between the existing status and requirements of lean manufacturing as per above classification.

Table: 1 Gap analysis

\begin{tabular}{|c|c|c|c|}
\hline AREA & STATUS & $\begin{array}{r}\text { LEAN } \\
\text { MANUFACTURING } \\
\text { REQUIREMENT }\end{array}$ & GAPS \\
\hline Defects & MEDIUM & zero & MEDIUM \\
\hline $\begin{array}{c}\text { Inventory } \\
\text { Excessive material movement } \\
\text { waste }\end{array}$ & HEDIUM & zero & HIGH \\
\hline Delays due to Waiting & HIGH & zero & HEDIUM \\
\hline Inappropriate processing & HIGH & zero & HIGH \\
\hline
\end{tabular}

\section{DEVELOPMENT OF GENERALIZED APPROACH}

For developing a generalized approach, the cost associated with a provision has been taken as the most important input. In the development of approach experts play important role. Experts are employees of the organizations, in all, a total of ten experts consisting of two managers, three supervisors; three operators, one inspector and one mechanic were selected. The experts were briefed about the findings of the root cause of wastes and the purpose of getting their feedback. All the experts who were selected had requisite amount of experience, education level and a realistic bent of mind. However, in the brain storming session the experts were requested, to first of all, identify factor and parameter, other than cost which must be considered for developing an implementation approach.

Factors and Parameters influencing Development of a Generalized Approach

The experts after discussion and brain storming conversed on the following factors influencing development of a generalized approach.

\section{Cost associated with the removal of cause.}

- $\operatorname{High}(\mathrm{H})$

- $\quad$ Medium (M)

- Low (L)

2. Ease of removal

- Easy (E)

- Not easy (N)

- Difficult (D)

3. Effect on other areas (can be positive or negative)

- $\operatorname{High}(\mathrm{H})$

- $\operatorname{Medium}(\mathrm{M})$ 
- $\quad \operatorname{Low}(\mathrm{L})$

After identifying these parameters a blank Performa was prepared. In this Performa, all the generalized categories of provisions/ controls .Expert provides the responses to each factor and parameter with regards to each general provision. These Performa's were circulated to experts who filled up the information in the requisite columns in qualitative terms for e.g. High (H), Medium (M) or Low (L). These qualitative scores were then converted into quantitative score using the scoring scale and the number of responses to a choice. The scoring scale is shown in table 2.

Table 2 Scoring scale for state of parameter.

\begin{tabular}{|c|c|c|c|}
\hline Sr. No. & Parameter & Constraint & Score \\
\hline 1. & $\begin{array}{c}\text { Cost associated with the implementation } \\
\text { of a provision. }\end{array}$ & $\begin{array}{cc} & \operatorname{High}(\mathrm{H}) \\
\bullet & \operatorname{Medium}(\mathrm{M}) \\
& \quad \text { Low }(\mathrm{L})\end{array}$ & $\begin{array}{l}1 \\
2 \\
3\end{array}$ \\
\hline 2. & Ease of removal & $\begin{array}{lc} & \text { Easy (E) } \\
-\quad & \text { Not Easy (N) } \\
-\quad & \text { Difficult (D) }\end{array}$ & $\begin{array}{l}3 \\
2 \\
1\end{array}$ \\
\hline 3. & Effect on other areas & 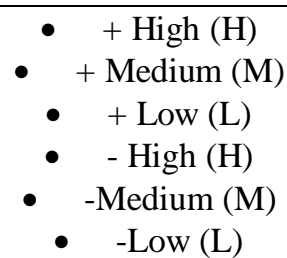 & $\begin{array}{c}3 \\
2 \\
1 \\
-1 \\
-2 \\
-3\end{array}$ \\
\hline
\end{tabular}

Table 3 depicts the summary of the responses received from experts. In this table number of experts responding to a particular choice in a factor or parameter has been compiled from the individual responses of the experts. Number of responses to a particular choice has then been multiplied by the score of that choice in every factor as listed in Table. Those weighted scores have been summed up against each generalized control or provision and have been listed in the last column of Table. The highest score of a provision in the column, depicts that considering all the above five factors and parameters, this generalized provision should be taken up for implementation.

Table 3 Responses of Experts

\begin{tabular}{|c|c|c|c|c|c|c|c|c|c|c|c|c|c|c|}
\hline \multirow[t]{3}{*}{$\begin{array}{l}\text { Was } \\
\text { tes }\end{array}$} & \multirow[t]{3}{*}{ Root cause of waste } & \multicolumn{3}{|c|}{ Cost } & \multicolumn{3}{|c|}{$\begin{array}{l}\text { Ease } \\
\text { of } \\
\text { remov } \\
\text { al }\end{array}$} & \multicolumn{6}{|c|}{ Effect of others } & \multirow[t]{3}{*}{$\begin{array}{l}\text { Cumulative } \\
\text { score. }\end{array}$} \\
\hline & & $\mathbf{H}$ & $\mathbf{M}$ & $\mathbf{L}$ & $\mathbf{E}$ & $\mathbf{N}$ & $\mathbf{D}$ & $\mathbf{H}$ & $\mathbf{M}$ & $\mathbf{L}$ & $\mathbf{H}$ & $\mathbf{M}$ & $\mathbf{L}$ & \\
\hline & & 1 & 2 & 3 & 3 & 2 & 1 & $\begin{array}{l}+ \\
3\end{array}$ & $\begin{array}{l}+ \\
2\end{array}$ & $\begin{array}{l}+ \\
1\end{array}$ & $\overline{1}$ & -2 & $\overline{3}$ & \\
\hline \multirow[t]{6}{*}{$\begin{array}{l}\text { Def } \\
\text { ect }\end{array}$} & Improper machining and equipment & 9 & 3 & 0 & 0 & 3 & 7 & 0 & 0 & 0 & 8 & 2 & 0 & 16 \\
\hline & $\begin{array}{c}\text { Poor quality of inputs like materials, } \\
\text { tools etc }\end{array}$ & 2 & 7 & 3 & 8 & 3 & 0 & 0 & 0 & 2 & 1 & 2 & 8 & 28 \\
\hline & $\begin{array}{c}\text { Human error on passing on } \\
\text { instructions }\end{array}$ & 1 & 2 & 7 & 8 & 3 & 0 & 0 & 2 & 2 & 8 & 1 & 0 & 52 \\
\hline & Human error by workers & 2 & 7 & 2 & 3 & 5 & 2 & 0 & 1 & 1 & 6 & 2 & 1 & 33 \\
\hline & $\begin{array}{l}\text { Wrong setting and determination of } \\
\text { parameters of temp, pressure etc. } \\
\text { and inefficient control system to } \\
\text { maintain them }\end{array}$ & 1 & 1 & 7 & 8 & 3 & 0 & 0 & 0 & 0 & 3 & 8 & 1 & 32 \\
\hline & $\begin{array}{l}\text { Scraping of product, this deviates } \\
\text { from drawing specifications but can } \\
\text { be used. }\end{array}$ & 0 & 2 & 8 & 9 & 3 & 0 & 0 & 1 & 8 & 0 & 0 & 0 & 69 \\
\hline $\begin{array}{l}\text { Inve } \\
\text { ntor }\end{array}$ & Arbitrary buying of material. & 0 & 1 & 7 & 6 & 4 & 1 & 0 & 0 & 0 & 2 & 6 & 1 & 33 \\
\hline
\end{tabular}




\begin{tabular}{|c|c|c|c|c|c|c|c|c|c|c|c|c|c|c|}
\hline \multirow[t]{7}{*}{$\mathrm{y}$} & $\begin{array}{l}\text { Buying gross requirement as per the } \\
\text { matter production schedule, net } \\
\text { requirement not calculated. }\end{array}$ & 1 & 4 & 6 & 9 & 3 & 0 & 0 & 0 & 0 & 8 & 3 & 0 & 46 \\
\hline & $\begin{array}{l}\text { For regular items techniques of } \\
\text { inventory control not used. }\end{array}$ & 3 & 7 & 2 & 6 & 3 & 0 & 0 & 0 & 1 & 7 & 3 & 0 & 25 \\
\hline & Poor record keeping and retrieval. & 1 & 3 & 8 & 9 & 2 & 0 & 0 & 0 & 3 & 6 & 2 & 0 & 55 \\
\hline & In balancing of production lines. & 8 & 3 & 1 & 0 & 6 & 4 & 0 & 0 & 1 & 2 & 6 & 0 & 20 \\
\hline & $\begin{array}{l}\text { Inventory levels between work } \\
\text { centers not worked out. }\end{array}$ & 9 & 3 & 0 & 0 & 4 & 7 & 2 & 8 & 0 & 1 & 3 & 0 & 43 \\
\hline & Bottlenecks in the processes. & 8 & 2 & 0 & 0 & 3 & 8 & 0 & 0 & 0 & 1 & 0 & 8 & 1 \\
\hline & $\begin{array}{l}\text { Deliberate attempt by production } \\
\text { people to keep higher inventories. }\end{array}$ & 0 & 6 & 4 & 0 & 3 & 7 & 0 & 0 & 1 & 3 & 6 & 0 & 23 \\
\hline \multirow{8}{*}{$\begin{array}{c}\text { Exc } \\
\text { essi } \\
\text { ve } \\
\text { mat } \\
\text { erial } \\
\text { mov } \\
\text { eme } \\
\text { nt }\end{array}$} & Improper layout. & 9 & 1 & 0 & 0 & 3 & 9 & 0 & 0 & 1 & 4 & 5 & 0 & 13 \\
\hline & $\begin{array}{l}\text { Storage is away from the production } \\
\text { shop. }\end{array}$ & 1 & 9 & 1 & 3 & 7 & 1 & 0 & 1 & 6 & 1 & 1 & 0 & 51 \\
\hline & $\begin{array}{l}\text { Old method or manual } \\
\text { transportation system. }\end{array}$ & 1 & 3 & 6 & 1 & 7 & 2 & 0 & 0 & 1 & 6 & 2 & 1 & 32 \\
\hline & $\begin{array}{l}\text { Expansion of shops not properly } \\
\text { planned resulting in too much } \\
\text { excessive movement. }\end{array}$ & 9 & 3 & 0 & 0 & 3 & 7 & 0 & 2 & 3 & 4 & 1 & 0 & 29 \\
\hline & Unaware of extent of loss. & 4 & 6 & 0 & 1 & 7 & 2 & 0 & 2 & 4 & 2 & 3 & 0 & 35 \\
\hline & $\begin{array}{l}\text { Inability of top management to plan } \\
\text { modernization. }\end{array}$ & 9 & 3 & 0 & 9 & 4 & 1 & 0 & 0 & 1 & 5 & 8 & 0 & 31 \\
\hline & $\begin{array}{l}\text { Poor understanding of process flow } \\
\text { for production. }\end{array}$ & 1 & 2 & 6 & 1 & 8 & 1 & 0 & 0 & 1 & 6 & 2 & 0 & 34 \\
\hline & $\begin{array}{c}\text { Large batch size, long lead-time and } \\
\text { large storage area }\end{array}$ & 4 & 6 & 0 & 1 & 7 & 2 & 0 & 0 & 1 & 3 & 7 & 0 & 19 \\
\hline \multirow[t]{6}{*}{$\begin{array}{l}\text { Dela } \\
\text { y } \\
\text { due } \\
\text { Wai } \\
\text { ting }\end{array}$} & $\begin{array}{l}\text { Workers present but not working } \\
\text { deliberately because of negative } \\
\text { attitude, union effects, lack of } \\
\text { motivation, low morale, no concern } \\
\text { and lack of a accountability. }\end{array}$ & 9 & 4 & 0 & 0 & 3 & 7 & 0 & 0 & 0 & 1 & 2 & 7 & 4 \\
\hline & Un-avoidable delays & 3 & 5 & 2 & 0 & 5 & 5 & 0 & 1 & 2 & 6 & 1 & 0 & 30 \\
\hline & Shortages of materials & 2 & 3 & 5 & 5 & 3 & 1 & 0 & 0 & 1 & 4 & 5 & 1 & 29 \\
\hline & $\begin{array}{c}\text { Break downs of machines and } \\
\text { equipment }\end{array}$ & 8 & 3 & 0 & 1 & 7 & 1 & 0 & 0 & 1 & 3 & 7 & 0 & 16 \\
\hline & $\begin{array}{c}\text { Excessive time spent on setting } \\
\text { because proper jigs and fixture are } \\
\text { not used. }\end{array}$ & 1 & 3 & 5 & 2 & 7 & 1 & 0 & 0 & 2 & 3 & 1 & 0 & 40 \\
\hline & Absenteeism & 8 & 3 & 0 & 5 & 5 & 0 & 0 & 0 & 0 & 5 & 5 & 0 & 24 \\
\hline \multirow{7}{*}{$\begin{array}{c}\text { Inap } \\
\text { prop } \\
\text { riate } \\
\text { proc } \\
\text { essi } \\
\text { ng }\end{array}$} & $\begin{array}{c}\text { Product changes without process } \\
\text { changes. }\end{array}$ & 0 & 7 & 3 & 3 & 8 & 1 & 0 & 0 & 3 & 4 & 2 & 0 & 50 \\
\hline & Poor machine effectiveness. & 1 & 6 & 2 & 2 & 7 & 1 & 0 & 0 & 3 & 5 & 1 & 0 & 36 \\
\hline & $\begin{array}{c}\text { Trace customer requirement } \\
\text { undefined. }\end{array}$ & 0 & 3 & 6 & 2 & 7 & 0 & 0 & 0 & 3 & 4 & 2 & 0 & 39 \\
\hline & $\begin{array}{l}\text { Over processing to accommodate } \\
\text { downtime. }\end{array}$ & 2 & 8 & 0 & 2 & 5 & 1 & 0 & 0 & 1 & 6 & 2 & 0 & 26 \\
\hline & Lack of communications. & 2 & 7 & 2 & 3 & 6 & 1 & 0 & 0 & 1 & 6 & 2 & 0 & 35 \\
\hline & Careless workers. & 0 & 8 & 2 & 0 & 8 & 2 & 0 & 0 & 1 & 7 & 1 & 0 & 32 \\
\hline & Extra copier/excessive information. & 0 & 2 & 8 & 8 & 2 & 0 & 0 & 2 & 7 & 2 & 1 & 0 & 63 \\
\hline
\end{tabular}

VI.

SUGGESTED IMPLEMENTATION PLAN

It was then decided to formulate a phase wise implementation approach by picking up the provisions which had higher weighted scores in the above five major areas. For deciding the number of provisions taken up for implementation in a phase, out of the total provisions under a major area, the proximity or differences of scores around the cutoff were considered i.e. there should be a considerable difference between 
the score of the last provision in a Phase 1 and the first provision of Phase 2 and so on. Based on all these considerations, the implementation of the provisions has been divided into three phases as an order of priority for implementation in any die casting industry. The three phases of the suggested approach are presented in Table 4.

Table 4(Suggested Implementation Plan)

\begin{tabular}{|c|c|c|c|c|c|}
\hline & Defects & Inventory & $\begin{array}{lll}\text { Delays } & \text { due } & \text { to } \\
\text { Waiting } & & \end{array}$ & $\begin{array}{l}\text { Excessive } \\
\text { material } \\
\text { movements } \\
\end{array}$ & $\begin{array}{l}\text { Inappropriate } \\
\text { Processing }\end{array}$ \\
\hline $\begin{array}{l}\mathrm{Ph} \\
\text { as } \\
\text { e } 1\end{array}$ & \begin{tabular}{|ll} 
- Scrapping of Product, \\
this deviates \\
from drawing \\
specification but \\
can be used \\
- Human error on \\
passing & on \\
instructions
\end{tabular} & $\begin{array}{l}\text { - Poor record } \\
\text { keeping and } \\
\text { retrieval } \\
\text { - Buying gross } \\
\text { requirement as } \\
\text { per the matter } \\
\text { production } \\
\text { schedule, net } \\
\text { requirement not } \\
\text { calculated }\end{array}$ & $\begin{array}{l}\text { - Excessive time } \\
\text { spent on setting } \\
\text { because proper } \\
\text { jigs and fixtures } \\
\text { are not used. } \\
\text { - Unavoidable delay }\end{array}$ & \begin{tabular}{|l} 
Storage away \\
from the \\
production shop. \\
- Unaware of \\
extent of loss \\
Poor understanding \\
und process \\
of flow \\
flow for \\
production
\end{tabular} & $\begin{array}{l}\text { Extra copier/ } \\
\text { excessive } \\
\text { information } \\
\end{array}$ \\
\hline $\begin{array}{l}\mathrm{Ph} \\
\text { as } \\
\text { e } 2\end{array}$ & $\begin{array}{l}\text { - Wrong setting and } \\
\text { determination of } \\
\text { parameters of } \\
\text { temperature, } \\
\text { pressure etc. and } \\
\text { inefficient control } \\
\text { system to maintain } \\
\text { them } \\
\text { - Human error by } \\
\text { worker }\end{array}$ & $\begin{array}{c}\text { - For regular } \\
\text { technique of } \\
\text { inventory } \\
\text { control not used. } \\
\text { - Inventory level } \\
\text { between work } \\
\text { centre not } \\
\text { worked out. } \\
\text { - Arbitrary buying } \\
\text { of material }\end{array}$ & $\begin{array}{lr}\text { - Shortage } & \text { of } \\
\text { materials } & \\
\text { - Absenteeism } & \\
\text { - Breakdowns } & \text { of } \\
\text { machines } & \text { and } \\
\text { equipments. } & \\
& \\
& \end{array}$ & $\begin{array}{l}\text { - Old method or } \\
\text { manual } \\
\text { transportation } \\
\text { system . } \\
\text { - Inability of top } \\
\text { management } \\
\text { to plan } \\
\text { modernization } \\
\text {.. }\end{array}$ & $\begin{array}{l}\text { - Trace customer } \\
\text { requirement } \\
\text { undefined } \\
\text { - Product changes } \\
\text { without process } \\
\text { change } \\
\text { - Poor machine } \\
\text { effectiveness }\end{array}$ \\
\hline $\begin{array}{l}\mathrm{Ph} \\
\text { as } \\
\text { e } 3\end{array}$ & $\begin{array}{l}\text { - Improper machining } \\
\text { and equipment } \\
\text { - Poor quality of inputs } \\
\text { like materials, } \\
\text { tools etc. }\end{array}$ & $\begin{array}{c}\text { - Deliberate attempt } \\
\text { by production } \\
\text { people to keep } \\
\text { higher inventory } \\
\text { - Bottlenecks in the } \\
\text { processes } \\
\text { - Imbalancing of } \\
\text { production line }\end{array}$ & $\begin{array}{l}\text { - Workers present but } \\
\text { not working } \\
\text { deliberately, } \\
\text { because of } \\
\text { negative attitude, } \\
\text { union, lack of } \\
\text { motivation, low } \\
\text { morale, no } \\
\text { concern and lack } \\
\text { of accountability. }\end{array}$ & $\begin{array}{l}\text { - Large batch, } \\
\text { long lead time } \\
\text { and large } \\
\text { storage area. } \\
\text { - Improper layout } \\
\text { - Expansion of } \\
\text { shops, } \\
\text { resulting } \\
\text { excessive } \\
\text { movement. }\end{array}$ & $\begin{array}{l}\text { - Careless workers } \\
\text { - Over processing } \\
\text { to } \\
\text { accommodate } \\
\text { downtime } \\
\text { - Lack of } \\
\text { communication }\end{array}$ \\
\hline
\end{tabular}

The provision or controls suggested to be implemented in Phase 1 will in general be less costly, easy to implement and would have positive or complementary effect on many other areas in the organization.

Phase 2 includes measures which are slightly more difficult to implement, involves reasonably higher cost, which may require some kind of budgetary provisions and approvals.

Phase 3 includes provisions, which are more related with hardcore technical changes, machinery, equipment and tooling. Implementation of these provisions will involve substantial capital investment and may require a number of iterations and trials for implementation.

\section{OTHER WASTE REDUCTION TECHNIQUES}

Some of the other waste reductions tools include zero defects, setup reduction and line balancing. The goal of zero defects is to ensure that products are fault-free all the way, through continuous improvement of the manufacturing process (Karlsson et al. 1996). Human beings almost invariably will make errors. When errors are made and are not caught then defective parts will appear at the end of the process. However, if the errors can be prevented before they happen then defective parts can be avoided. One of the tools that the zero-defect principle uses is poka-yoke. Poka-yoke, which was developed by Shingo, is an autonomous defect control system that is put on a machine that inspects all parts to make sure that there are zero defects. The goal of pokayoke is to observe the defective parts at the source, detect the cause of the defect, and to avoid moving the defective parts to the next workstation (Feld, 2000). Ohno at Toyota developed SMED in 1950. Ohno's idea was to develop a system that could exchange dies in a more speedy way. By the late 1950's Ohno was able to reduce the time that was required to change dies from a day to three minutes (Womack et al, 1990). The basic idea of SMED is to reduce the set up time on a machine. There are two types of setups: internal and external. Internal setup activities are those that can be carried out only while the machine is stopped while external setup activities 
are those that can be done while the machine is running. The idea is to move as many activities as possible from internal to external (Feld, 2000). After all the activities are identified then the next step is to try to simplify these activities. By reducing the setup time many benefits can be realized. First, die-change specialists are not needed. Inventory can be reduced by producing small batches and more variety of product mix can be run. Line balancing is considered a great weapon against waste, especially the wasted time of workers. The idea is to make every workstation produce the right volume of work that is sent up upstream workstations without any stoppage. This will ensure that each workstation is working in a synchronized manner, neither faster nor slower than other stations.

\section{REFERENCES}

[1] Shingo, S., 1987. The Sayings of Shigeo Shingo: Key Strategies for Plant Improvement. Productivity Press, Cambridge, MA.

[2] Black, J.T., Hunter, S.L., 2003. Lean Manufacturing Systems and Cell Design. Society of Manufacturing Engineers, Dearborn, MI.

[3] Conner, G., 2001. Lean Manufacturing for the Small Shop. Society of Manufacturing Engineers, Dearborn, MI.

[4] Jordan, J.A., Jr., Michel, F.J., 1999. Valuing Lean Manufacturing Initiatives. Society of Manufacturing Engineers Technical Paper No. MS01-104, pp. 1-15.

[5] M. Brian Thomas, Laboratory exercises for teaching lean enterprise, Proceedings of ASEE Conference and Expo, 2007.

[6] Joseph Chen, Ronald Cox, Win-Win-Win Curriculum in Lean/Six Sigma Education at Iowa State University, Proceedings of ASEE Conference and Expo, 2007.

[7] www.leanproduction.com.

[8] Jim Parrie, (2007). Minimize Waste With the 5S System. Retrieved from www.pfmproduction.com/pdfs/PFMP.../PFMP_Spring07_Waste.pdf.

[9] Jones D., and Womack, J., (2003), "Seeing the Whole - Mapping the extended Value Stream", The Lean Enterprise Institute, Brookline, USA

[10] Lean Manufacturing and the Environment .(2010). Cellular Manufacturing. Retrieved April 26, 2010, from http://www.epa.gov/lean/thinking/cellular.htm.

[11] Taiichi, Ohno. (1988). Toyota Production System - beyond large-scale production. Productivity Press. 25-28.

[12] Womack J., Jones D. T. \& Roos D. (1991). The machine that changed the world - The story of lean production. HarperPerennial, New York.

[13] Kenney, M. and Florida, R. (1993). Beyond Mass Production. Oxford University Press, Oxford.

[14] Koskela, L. (1997). "Towards the Theory of Lean Construction." Proc. 5th IGLC Conference, Gold Coast, Australia.

[15] Melles, B. (1994). "What do we Mean by Lean Production in Construction?" Proc. $2^{\text {nd }}$ Workshop on Lean Construction, Santiago, in Alarcon 1997.

[16] Seymour, D., Rooke, J., and Crook, D. (1997). "Doing Lean Construction and Talking about Lean Construction." Proc. 5th IGLC Conference, Gold Coast, Australia.

[17] A. Sahoo, N. Singh and R. Shankar, (2008). "Lean philosophy: implementation in a forging company." The International Journal of Advanced Manufacturing Technology 36(5): 451-462.

[18] A. Badurdeen (2007), "Lean manufacturing basics", http://www.leanmanufacturingconcepts.com.

[19] Feld, William M., Lean Manufacturing: Tools, Techniques and How to Use Them. Boca Raton, FL: St. Lucie Press, 2000

[20] Cua, Kristy O., Kathleen E. McKone \& Roger G. Schroeder (2001). Relationships between implementation of TQM, JIT, and TPM and manufacturing performance. Journal of Operations Management, Vol. 19, pp. 675-694.

[21] Karlsson, C. and Åhlström, P., (1996), “Assessing changes towards lean production”, International Journal of Operations \& Production Management 16, pp 24-41.

[22] Wilson, L. (2010), How To Implement Lean Manufacturing. New York: McGraw-Hill.

[23] Basic concepts of Lean Manufacturing- WWW.TWINETWORK.COM.

[24] Tom Gust- "Leading the Implementation of Lean Manufacturing", Athabasca University December 2011. 